\title{
State and ways to increase soil fertility of the south-steppe zone of Ukraine
}

\author{
Holoborodko S. ${ }^{1}$, Dymov O. ${ }^{2}$ \\ Institute of Irrigated Agriculture of NAAS \\ set. Naddniprianske, Kherson, 73483, Ukraine \\ e-mail: ${ }^{2}$ goloborodko1939@gmail.com, 21 ksndrdymov@gmail.com \\ ORCID: ${ }^{1}$ http://orcid.org/0000-0002-6968-985X, ${ }^{2}$ https://orcid.org/0000-0002-7839-0956
}

Goal. To scientifically substantiate the modern landscape-ecological state of agricultural lands and the development of agrobiological measures to increase the fertility of degraded dark chestnut soils of the Steppe zone of Ukraine in conditions of natural moisture. Methods. Field - to study the interaction of the research object with biotic and abiotic factors of the Steppe zone; physicochemical - to establish the fertility of dark chestnut soil and to determine the chemical composition of plants; comparable calculation - to conduct the economic and energy evaluation of growing legumes of long-term grasses; dispersion analysis - to determine the reliability of the results of scientific research. Results. The area of perennial grasses in the Steppe zone over the past 10 years had significantly decreased. That created real risks to enhance the processes of water and wind erosions of soils. Significant influence on the efficiency of agricultural production in the Steppe zone also had regional climate change. In studies on the selection of perennial legumes and cereals as well as legume-cereal grass mixtures, accumulation of symbiotic nitrogen by Lucerne in the first year of the use of mono-species crops was $60 \mathrm{~kg} / \mathrm{ha}$, by mixture Lucerne + Bromus inermis - 68, and by Sainfoin - 105-118 $\mathrm{kg} / \mathrm{ha}$. In the $2 \mathrm{nd}$ year of the use of herbs, the accumulation of symbiotic nitrogen was also high $-37-55$ $\mathrm{kg} / \mathrm{ha}$ in Lucerne, and $52-80 \mathrm{~kg} / \mathrm{ha}$ in Sainfoin. In the 3rd year of the use of grasses its accumulation decreased to $36-37 \mathrm{~kg} / \mathrm{ha}$ in Lucerne, and to $15-22 \mathrm{~kg} / \mathrm{ha}$ - in Sainfoin. The fractional composition of nitrogen in the $0-20 \mathrm{~cm}$ and $20-40 \mathrm{~cm}$ layers of dark chestnut soil after the 3-year use of Lucerne in comparison to other levels of crop rotation was the highest and depending on the soil layer made: of the total $-1006.3-1428.8 \mathrm{mg} / \mathrm{kg}$, of mineral $-24,9-46,3$, of alkaline hydrolyzed $-113,8-186,0$, of heavyhydrolyzed $-155,5-214,4$, non- $-712,1-982,1 \mathrm{mg} / \mathrm{kg}$ of soil. Conclusions. One of the main areas of decrease in the processes of degradation and preservation and increase of soil fertility is the creation of highperformance mono-species agro phytocoenoses of perennial legumes and binary legume-cereal grass mixtures, resistant to regional climate change in the steppe zone of Ukraine.

Key words: degradation, climate, structure of sowing areas, symbiotic nitrogen, Lucerne, Sainfoin, Bromus inermis.

DOI: https://doi.org/10.31073/agrovisnyk202104-02

The Steppe zone of Ukraine is home to the world's richest chernozem soils, but currently almost all of them are plowed, about $80 \%$ of the territory is occupied by agricultural land. As a result, soil fertility is catastrophically deteriorating, and degradation processes are increasing. The total area of only eroded land here is more than $38 \%$, that is, more than 11 million hectares, including 5 million hectares exposed to wind erosion [1].

Due to the lack of scientifically based farming systems and, above all, non-compliance with the optimal structure of acreage, the introduction of insufficient amounts of organic and mineral fertilizers in soils, the content of humus and mineral nutrients is significantly reduced.

Fixing with nodule blocks bacteria nitrogen from the atmosphere, alfalfa on unirrigated lands accumulates up to $120-150 \mathrm{~kg} / \mathrm{ha}$ symbiotic nitrogen, which is equivalent to $3.5-4.3 \mathrm{c} / \mathrm{ha}$ of mineral nitrogen in the form of ammonium nitrate. Therefore, the study of the accumulation of symbiotic nitrogen in the soil during the cultivation of perennial legumes in the Steppe zone is of great importance and makes it possible to correct the structure of sown areas, fertilizer systems and improve existing technologies for growing agricultural crops based on the established patterns of its change [2].

Regional climate changes have also had a huge impact on the formation of crop productivity in recent years [3]. An increase in air temperature and an increase in climate aridity create additional risks for increasing water and wind erosion of soils $[4,5]$. In addition, in the South there is a tendency to increase the processes that cause the occurrence of dust storms.

The purpose of the research is scientific substantiation of the modern landscape and ecological system state of agricultural land and development in conditions of natural moisture (without irrigation) agrobiological measures on increasing the fertility of degraded dark-chestnut soils of the southern-steppe zone of Ukraine.

Research methods. Field experiments on the tinning of arable land were conducted in the State Enterprise "Experimental Farm "Kopani" IIA of NAAS in 2010-2019. The soil of the experimental sites is dark-chestnut, residual slightly saline, medium loamy, with the content in the arable layer: humus (according to Tyurin) $2.02-2.34 \%$, nitrate nitrogen $\left(\mathrm{N}-\mathrm{NO}_{3}\right)-8.0-12.3 \mathrm{mg} / \mathrm{kg}$; mobile phosphorus (according to Machihin) $-24.2-$ 
36.3 and exchange potassium $-330-413 \mathrm{mg} / \mathrm{kg}$ of soil. Due to the lack of moisture in dry (95\%) years of precipitation availability, the soil cracked to a depth of $0.5-0.7$ meters (fig. 1).

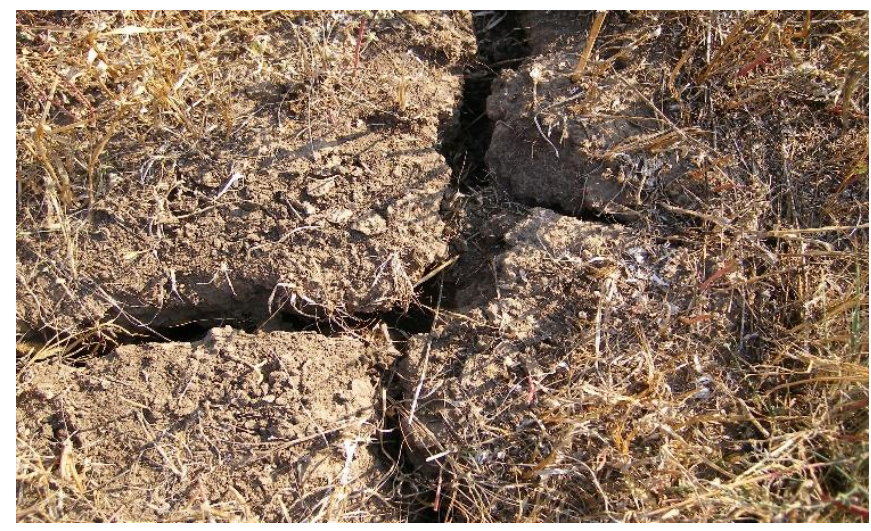

\section{Fig. 1. The state of unirrigated dark-chestnut soil of the Southern Steppe subzone in summer during dry years in terms of precipitation availability}

At the same time, the yield of cultivated crops in previous crop rotations decreased by $10-20 \%$ or more, which are, in particular, signs of soil degradation.

Irrigation of arable land was carried out with cereals and legumes of perennial grasses, the biological features of which are most adapted to the natural and climatic conditions of the Southern Steppe. For short-term (no more than 2-3 years) use of single-species crops of cereals and legumes of perennial grasses, Iolium multiflorum (Lolium multiflorum Lam.) Yaroslav variety and sainfoin (Onobrychis arenaria Kit.) Ingulsky variety. During the medium-term reproduction of soil fertility (3-4 years), used festuca orientalis (Festuca orientalis (Hack.) V. Krecz.) Domenica variety and variable lucerne (Medicago varia T. Martyn.) Veselka variety.

For long-term reproduction of the fertility of dark-chestnut soil, used variable lucerne (Medicago varia T. Martyn) Veselka variety and bromus inermis (Bromopsis inermis (Leyss.) Holub) Tavriyskyi variety.

Sowing of perennial grasses and legumes in single-species crops and binary grass mixtures was carried out in early spring for three years (2016-2019). The seeding rate for short-term reproduction of the fertility of degraded dark-chestnut arable land, for $100 \%$ of its economic suitability, in monofilament crops was: Iolium multiflorum $-24 \mathrm{~kg} / \mathrm{ha}$, festuca orientalis -24 ; sainfoin -80 ; as part of grass mixtures, respectively $-12 ; 12$ and $60 \mathrm{~kg} / \mathrm{ha}$.

For long - term reproduction of land fertility, the seeding rate of lucerne seeds in single-species crops was $24 \mathrm{~kg} / \mathrm{ha}$ and bromus inermis - $28 \mathrm{~kg} / \mathrm{ha}$. As part of binary grass mixtures, the seeding rate was: lucerne + bromus inermis $-12+14 \mathrm{~kg} / \mathrm{ha}$. The sown area is $60 \mathrm{~m}^{2}$, the accounting area is $20 \mathrm{~m}^{2}$. Crop accounting was carried out by the mowing method.

Determination of the amount of fixed nitrogen from the atmosphere by lucerne and sainfoin was carried out by a comparative method with bromus inermis, since when growing it with perennial legumes, all plant species consumed the same amount of nitrogen from the soil. The established difference between nitrogen removal in lucerne, sainfoin, and bromus inermis was equated to nitrogen fixed in legumes.

The dry matter content, the density of herbage, changes in the species botanical composition, the yield of feed units, gross and metabolic energy were determined according to generally accepted methods [6]. Fractional composition of soil nitrogen - according to E. I. Shkonde - I. Ye. Korolyova [7]. Evaporation rate (Eo), lack of moisture supply ( $\Delta \mathrm{Eo})$ by years of research were determined by N. M. Ivanov [8]. Statistical analysis of the yield of perennial grasses was carried out by the method of variance analysis [9].

Results of research. The structure of land use in developed countries of the world is optimized, since up to $40-50 \%$ of the land is occupied by protected landscapes, i.e. meadows and forests. The most striking example of inefficient use of land resources is the existing structure of acreage, which has developed over the past 30 years in the Steppe zone of Ukraine. With a total area of arable land equal to 15528.7 thousand hectares, due to the removal of legumes and perennial grasses from the structure of sown areas, the area of eroded land in recent years has increased to 8362.0 thousand hectares, or $53.8 \%$ of the total arable land area [1].

Compared to 1990, the acreage of forage crops, according to the State statistics service of Ukraine, has significantly decreased. If the area of perennial grasses in 1990 was 3986.6 thousand hectares, then in 2020 it did not exceed 869.3 thousand hectares, including in the Steppe zone - only 119.2 thousand hectares [10]. Because of this, over the past 10 years, soils of all types have begun to develop intensively erosion processes. In addition for growing for most agricultural crops, only mineral fertilizers were used, while organic fertilizers were almost never used. The latter is due to a reduction in the number of cattle, as a result of which the production of organic fertilizers decreased to 9.8 million tons and only 0.5 tons were applied per 1 ha of sown area. 
According to the structure of the acreage that has developed, it can be noted that the main direction of economic activity of existing enterprises was the cultivation of grain and industrial crops, primarily winter wheat, winter and spring barley, corn, sunflower, soybeans and winter rapeseed, which are in demand on the world market (fig. 2).

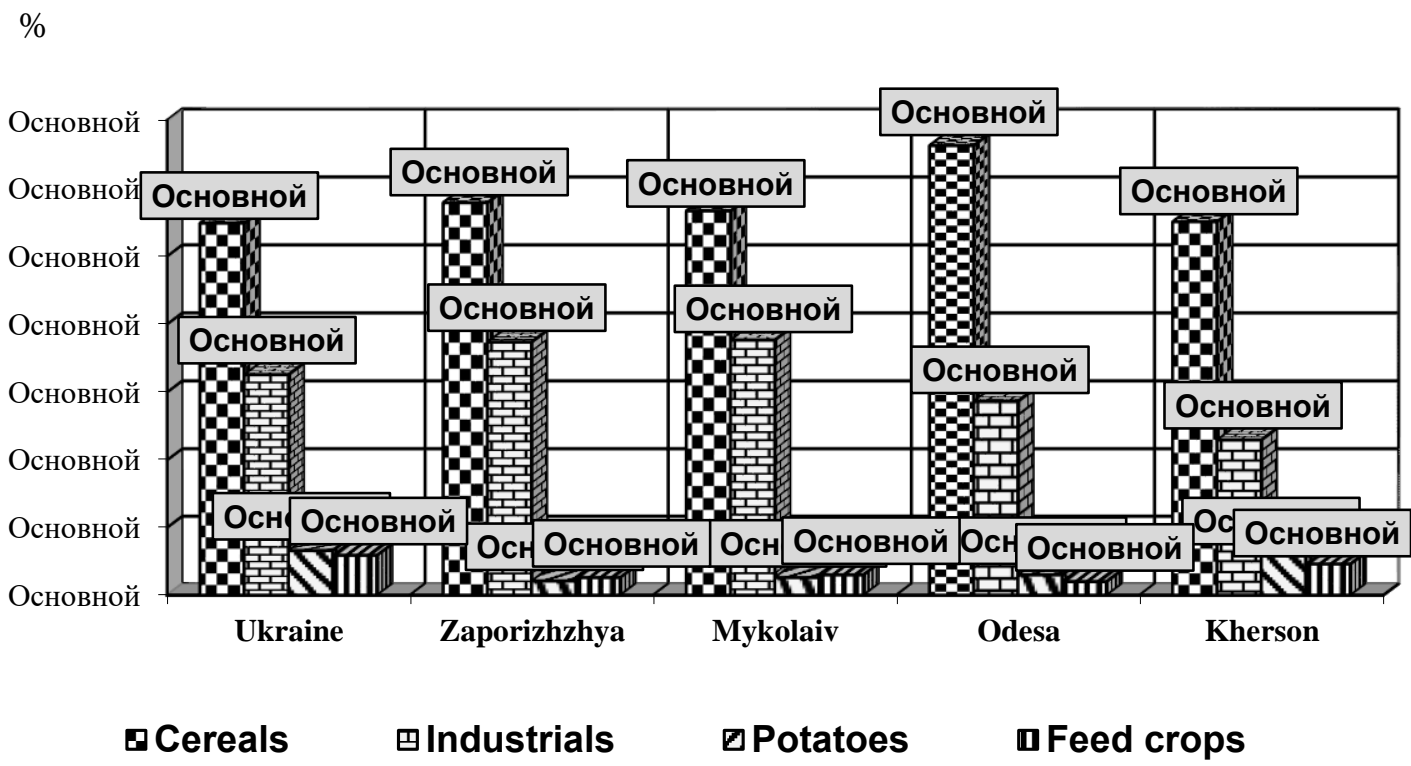

Fig. 2. Structure of sown areas of agricultural crops in Ukraine and the regions of the Southern Steppe in 2020 (according to the State statistics services of Ukraine)

The systematic expansion of sown areas of grain and industrial crops in the Steppe zone led to an unstable state of the created agricultural landscapes, the plowing of which at the beginning of the XXI century in Ukraine was $78.5 \%$, including in the Steppe zone - 81.3\%, in particular in: Kherson region - 90.2\%, Kirovohrad region - 86.4; Mykolaiv - 84.5; Zaporizhzhya - 84.8; Dnipropetrovsk - 84.5; Donetsk - 81.0; Odesa - 79.7 and Luhansk region $-66.4 \%$ [11].

Along with the use of scientifically unfounded farming systems, regional climate change has also had a significant impact on the efficiency of agricultural production in the Steppe zone [12]. If droughts for 400 years in the XI-XIV centuries occurred only 8 times, respectively, in the XVII-XVIII - 17, in the XIX - 20, then in the $\mathrm{XX}$ century their number increased to 30 . Therefore, currently the water resources of the Steppe zone of Ukraine are characterized as extremely insufficient, the shortage of moisture supply of agricultural crops in recent years (2018-2020) on the example of the Kherson region reaches 783.9-811.5 mm against $493.8 \mathrm{~mm}$ on average for 65 years (1945-2010) (fig. 3).

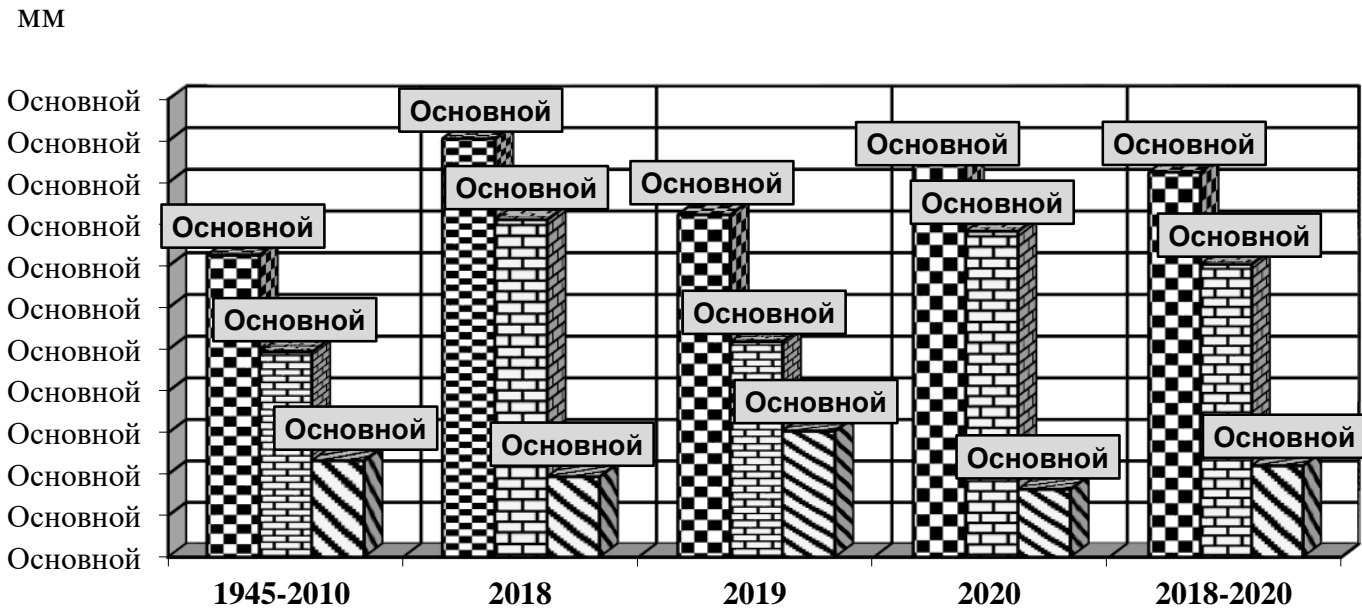
巴EO, MM
G $\triangle$ EO, MM
DP, мм

Fig. 3. Evaporation rate (Eo), lack of moisture supply ( $\triangle E O)$ and precipitation (P) during the growing season (April-September) in the Southern Steppe of Ukraine (according to the meteorological station of Kherson) 
In conditions of natural moisture (without irrigation), in late May-early June, most ephemeral and ephemerid grass species stop their growth and development or completely die off. Therefore, these types of meadow grasses, especially in dry (95\%) years of precipitation availability, do not have a significant impact on the formation of high yields and increasing the fertility of arable land. In this regard, over the past five years, scientific studies have been conducted at the Institute of Irrigated Agriculture of NAAS on the selection of legumes and cereals of perennial grasses and legume grass mixtures, establishing their productivity and impact on soil fertility.

The accumulation of symbiotic nitrogen in lucerne in the first year of using single view crops reached 60 $\mathrm{kg} / \mathrm{ha}$, and grass mixtures of lucerne + bromus inermis $-68 \mathrm{~kg} / \mathrm{ha}$, with a nitrogen fixation coefficient of $33.5 \%$ and $36.4 \%$, respectively, which is equivalent to $174-198 \mathrm{~kg} / \mathrm{ha}$ of mineral nitrogen in the form of ammonium nitrate, or 15.1-17.2 GJ/ha of total energy. Sainfoin with a nitrogen fixation coefficient of $46.9-49.8 \%$ accumulated up to $105-118 \mathrm{~kg} / \mathrm{ha}$ of symbiotic nitrogen, which is equivalent to $305-343 \mathrm{~kg} / \mathrm{ha}$ of mineral nitrogen, or 26.5-29.7 GJ/ha of total energy (table. 1).

\section{Accumulation of symbiotic nitrogen by Lucerne and Sainfoin depending on the duration of use of herbage by year (on average, over three years of research)}

\begin{tabular}{|c|c|c|c|c|c|c|}
\hline \multirow{2}{*}{ Indicators } & \multicolumn{3}{|c|}{ Lucerne } & \multicolumn{3}{|c|}{ Sainfoin } \\
\hline & $\mathrm{L}$ & $\mathrm{BI}$ & $\mathrm{L}+\mathrm{BI}$ & $\mathrm{S}$ & $\mathrm{BI}$ & $S+B \mid$ \\
\hline \multicolumn{7}{|c|}{ First year of use } \\
\hline Nitrogen removal by crop, $\mathrm{kg} / \mathrm{ha}$ & 179 & 119 & 187 & 237 & 119 & 224 \\
\hline$\%$ & 150 & 100 & 157 & 199 & 100 & 188 \\
\hline including symbiotic, $\mathrm{kg} / \mathrm{ha}$ & 60 & - & 68 & 118 & - & 105 \\
\hline Nitrogen fixation coefficient, \% & 33.5 & - & 36.4 & 49.8 & - & 46.9 \\
\hline $\begin{array}{l}\text { Atmospheric nitrogen fixation by equivalent to } \\
\text { mineral nitrogen in the form of ammonium nitrate, } \\
\mathrm{kg} / \mathrm{ha}\end{array}$ & 174 & - & 198 & 343 & - & 305 \\
\hline GJ/ha & 15.1 & - & 17.2 & 29.7 & - & 26.5 \\
\hline \multicolumn{7}{|c|}{ Second year of use } \\
\hline Nitrogen removal by crop, $\mathrm{kg} / \mathrm{ha}$ & 174 & 119 & 156 & 203 & 123 & 175 \\
\hline$\%$ & 146 & 100 & 131 & 165 & 100 & 142 \\
\hline including symbiotic, $\mathrm{kg} / \mathrm{ha}$ & 55 & - & 37 & 80 & - & 52 \\
\hline Nitrogen fixation coefficient, \% & 31.6 & - & 23.7 & 39.4 & - & 29.7 \\
\hline $\begin{array}{l}\text { Atmospheric nitrogen fixation by equivalent to } \\
\text { mineral nitrogen in the form of ammonium nitrate, } \\
\mathrm{kg} / \mathrm{ha}\end{array}$ & 160 & - & 107 & 233 & - & 151 \\
\hline GJ/ha & 13.9 & - & 9.3 & 20.2 & - & 13.1 \\
\hline \multicolumn{7}{|c|}{ Third year of use } \\
\hline Nitrogen removal by crop, kg/ha & 150 & 114 & 151 & 125 & 110 & 132 \\
\hline$\%$ & 132 & 100 & 132 & 114 & 100 & 120 \\
\hline including symbiotic, $\mathrm{kg} / \mathrm{ha}$ & 36 & - & 37 & 15 & - & 22 \\
\hline Nitrogen fixation coefficient, \% & 24.0 & - & 24.5 & 12.0 & - & 16.7 \\
\hline $\begin{array}{l}\text { Atmospheric nitrogen fixation by equivalent to } \\
\text { mineral nitrogen in the form of ammonium nitrate, } \\
\mathrm{kg} / \mathrm{ha}\end{array}$ & 105 & - & 108 & 44 & - & 64 \\
\hline GJ/ha & 9.1 & - & 9.3 & 3.8 & - & 5.5 \\
\hline
\end{tabular}

Note: $L$ - lucerne; $B I$ - bromus inermis; $L+B I$ - lucerne + bromus inermis; $S$ - sainfoin; $S+B I$ - sainfoin + bromus inermis.

In the second year of grass use, the accumulation of symbiotic nitrogen in lucerne and sainfoin was also high - 37-55 kg/ha in lucerne and $52-80 \mathrm{~kg} / \mathrm{ha}$ in sainfoin, with a nitrogen fixation coefficient of $23.7-31.6 \%$ and $29.7-39.4 \%$, respectively. The fixation of atmospheric nitrogen by lucerne in the given dimensions was equivalent to mineral nitrogen - up to $107-160 \mathrm{~kg} / \mathrm{ha}$.

In the third year of using perennial legume stands, the accumulation of symbiotic nitrogen by crops decreased to $36-37 \mathrm{~kg} / \mathrm{ha}$ in lucerne and $15-22 \mathrm{~kg} / \mathrm{ha}$ in sainfoin, which is associated with a change in the species botanical composition of sown herbage, primarily a significant decrease in the content of lucerne and sainfoin in the composition of herbage.

Cultivation of single-species crops of lucerne and sainfoin and their grass mixtures with a bromus inermis for three years of use made it possible to obtain green feed, balanced in digestible protein, without applying mineral fertilizers and have the best precursors for grain crops during all the years of cultivation. 
The determined fractional composition of nitrogen in $0-20 \mathrm{~cm}$ and $20-40 \mathrm{~cm}$ layers of dark chestnut soil of the experimental field of SE "EF "Kopani" indicates that after three years of lucerne use for inoculation of seeds with Ecovital, compared with other links of crop rotation, it was the highest and, depending on the soil layer, was: total - 1006.3-1428.8 $\mathrm{mg} / \mathrm{kg}$, respectively, mineral - 24.9-46.3; alkaline hydrolyzed - 113.8-186.0; hard-to-hydrolyze - 155.5-214.4 and non-hydrolyzed - 712.1-982.1 mg/kg of soil (table. 2).

2. Fractional composition of nitrogen in dark-chestnut soil of SE "EF "Kopani" of the Institute of Irrigated Agriculture of NAAS (2019)

\begin{tabular}{|c|c|c|c|c|c|c|}
\hline \multirow{2}{*}{$\begin{array}{c}\text { Crop rotation } \\
\text { link }\end{array}$} & \multirow{2}{*}{$\begin{array}{l}\text { Soil layer } \\
\text { depth, cm }\end{array}$} & \multicolumn{5}{|c|}{ Fractional composition of nitrogen, $\mathrm{mg} / \mathrm{kg}$} \\
\hline & & total & mineral $^{*}$ & $\begin{array}{c}\text { alkaline } \\
\text { hydrolyzed }\end{array}$ & $\begin{array}{l}\text { hard-to- } \\
\text { hydrolyze }\end{array}$ & $\begin{array}{c}\text { non-hydro- } \\
\text { lyzed }\end{array}$ \\
\hline \multirow{2}{*}{ Люцерна } & $0-20$ & 1428.8 & 46.3 & 186.0 & 214.4 & 982.1 \\
\hline & $20-40$ & 1006.3 & 24.9 & 113.8 & 155.5 & 712.1 \\
\hline \multirow{2}{*}{$\begin{array}{l}\text { Пшениця } \\
\text { озима }\end{array}$} & $0-20$ & 1176.0 & 19.2 & 121.2 & 179.7 & 855.9 \\
\hline & $20-40$ & 892.0 & 21.1 & 95.1 & 132.6 & 643.2 \\
\hline \multirow{2}{*}{ Соняшник } & $0-20$ & 1123,0 & 22.3 & 110.7 & 168.4 & 821.6 \\
\hline & $20-40$ & 834.0 & 12.6 & 81.6 & 127.1 & 612.7 \\
\hline \multirow{2}{*}{ Пар чорний } & $0-20$ & 1231,0 & 39.4 & 146.4 & 170.8 & 874.4 \\
\hline & $20-40$ & 917,0 & 25.1 & 99.5 & 134.3 & 658.1 \\
\hline \multicolumn{2}{|c|}{ SSD $05(0-20 \mathrm{~cm}), \mathrm{mg} / \mathrm{kg}$} & 152.90 & 15.03 & 38.34 & 24.36 & 79.32 \\
\hline \multicolumn{2}{|c|}{ SSD $05(20-40 \mathrm{~cm}), \mathrm{mg} / \mathrm{kg}$} & 82.04 & 6.69 & 15.19 & 14.28 & 47.62 \\
\hline
\end{tabular}

${ }^{*}$ Note: mineral nitrogen $-\left(\mathrm{N}-\mathrm{NO}_{3}+\mathrm{N}-\mathrm{NH}_{4}\right)$.

The creation of lucerne and lucerne-cereal agrocenoses in the southern part of the Steppe zone is economically justified. Conditionally, the net profit for growing single - species lucerne crops, regardless of the year of use of grass stands, reached UAH 2,130-5,580/ha. Profitability level lucerne accounted for $155-385 \%$, binary grass mixtures $-39-143 \%$.

\section{Conclusions}

The main direction that reduces the manifestation of soil degradation in modern economic conditions in the Southern Steppe is the creation of highly productive single-species agrophytocenoses of lucerne and binary lucerne grass mixtures. The productivity of single-species lucerne crops in conditions of natural moisture (without irrigation) reaches 1.33-2.67 t/ha of feed units and 0.30-0.62 t/ha of digestible protein, which allows increasing the production of feed balanced in digestible protein.

An increase in the acreage of single-species lucerne and lucerne grass mixtures helps to reduce the ecological load on agricultural land and significantly increase the content of fractional nitrogen composition in dark-chestnut soil, which allows having better predecessors for cereals, legumes and industrial crops.

Further ignoring the introduction of this direction of increasing fertility soils in the Steppe zone will lead to an even more critical condition and complete degradation.

\section{References}

1. Baliuk, S.A., Medvediev, V.V., Tarariko, O.H., Hrekov, V.O., \& Balaiev, A.D. (ed.). (2010). Natsionalna dopovid pro stan rodiuchosti hruntiv Ukrainy [National report on the state of soil fertility in Ukraine]. Kyiv: Minahropolityky, Tsentrderzhrodiuchist, NAAN, NNTs "IHA im. O.N. Sokolovskoho", NUBIP [in Ukrainian].

2. Awale, R., Emeson, M.A., \& Machado, S. (2017). Soil organic carbon pools as early indicators for soil organic matter stock changes under different tillage practices in Inland Pacific Northwest. Front. Ecol. Evol., 5(96). doi: 10.3389/fevo.2017.00096

3. Olsson, L., Barbosa, H., Bhadwal, S. et al. (2019). Land Degradation. In: Climate Change and Land: an IPCC special report on climate change, desertification, land degradation, sustainable land management, food security, and greenhouse gas fluxes in terrestrial ecosystems. Special Report on climate change and land (SRCCL).

4. Borrelli, P., Robinson, D.A., Panagos, P. et al. (2020). Land use and climate change impacts on global soil erosion by water $(2015$ - 2070). Proceedings of the National Academy of Sciences, 117 (36), 21994-22001. doi: 10.1073/pnas.2001403117

5. Dharumarajan, S., Veeramani, S., Kalaiseloi, B. et al. (A. Karmaoui (Ed.)). (2019). Potential Impacts of Climate Change on Land Degradation and Desertification: Land Degradation and Climate Change. Climate Change and Its Impact on Ecosystem Services and Biodiversity in Arid and Semi-Arid Zones, IGI Global, 183-195. doi: 10.4018/978-1-5225-7387-6.ch010

6. Dmytrochenko, A.P. (1978). Teoreticheskiie osnovy enerheticheskoho pitaniia zhyvotnykh [Theoretical foundations of energy nutrition of animals]. Vestnik selskohoziaistvennoi nauki Bulletin of agricultural Science, 9, 57-67 [in Russian]. 
7. Pannikov, V.D. (Ed.). (1986). Methodological recommendations for conducting research in longterm experiments with fertilizers. Moscov: VIUA, Part 1 [in Russian].

8. Ivanov, N.N. (1962). Pokazatel biolohicheskoi effektivnosti klimata [An indicator of the biological effects of climate]. Izvestiia Vsesoiuznoho heohraficheskoho obshchestva - Proceedings of the AllUnion Geographical Society, 94, 1, 65-70 [in Russian].

9. Ushkarenko, V.O., Vozhehova, R.A., Holoborodko, S.P., \& Kokovikhin, S.V. (2013). Statystychnyi analiz rezultativ poliovykh doslidiv u zemlerobstvi [Statistical analysis of the results of field experiments in agriculture]. Kherson: Ailant [in Ukrainian].

10. Posivni ploshchi silskohospodarskykh kultur pid urozhai 2020 roku: stat. biul. [Acreage of agricultural crops for the 2020 harvest: Statistical Bulletin]. (2020). Kyiv: Derzhavna sluzhba statystyky Ukrainy [in Ukrainian].

11. Halushkina, T.P. (2009). Ekonomika pryrodokorystuvannia: Navchalnyi posibnyk [Economics of nature Management: a textbook]. Kharkiv: Burun Knyha [in Ukrainian].

12. Konferentsyia OON po okruzhaiushchei srede i razvitiiu [United Nations Conference on Environment and Development] (n.d.). Ratsyonalnoie ispolzovaniie ekosistem: borba $\mathrm{s}$ opustynivaniiem i zasukhoi [Sustainable use of ecosystems: combating desertification and drought.] Retrieved from https://web.archive.org/web/20110420002837/http://www.uncsd2012. org/ [in Russian]. 